\title{
CADMIUM AND ZINC INDUCED SIMILAR CHANGES IN PROTEIN AND GLYCOPROTEIN PATTERNS IN TOBACCO (NICOTIANA TABACUM L.) SEEDLINGS AND PLANTS
}

\author{
Petra PEHAREC ŠTEFANIĆ ${ }^{1}$, Sandra ŠIKIĆ ${ }^{2}$, Petra CVJETKO $^{1}$, and Biljana BALEN ${ }^{1}$ \\ Department of Molecular Biology, Faculty of Science, University of Zagreb, Zagreb, Croatial , Department of Ecology, \\ Institute of Public Health, Zagreb, Croatia ${ }^{2}$
}

Received in November 2011

CrossChecked in January 2012

Accepted in July 2012

\begin{abstract}
The effects of $10 \mu \mathrm{mol} \mathrm{L} \mathrm{L}^{-1}$ and $15 \mu \mathrm{mol} \mathrm{L} \mathrm{L}^{-1}$ cadmium (Cd), a nonessential toxic element and $25 \mu \mathrm{mol} \mathrm{L}$ and $50 \mu \mathrm{mol} \mathrm{L}^{-1}$ zinc $(\mathrm{Zn})$, an essential micronutrient, on proteins and glycoproteins of Nicotiana tabacum L. seedlings and plants were investigated after exposure to each metal alone or to their combinations. Changes in only few polypeptides related to heavy metal treatments were observed in tobacco seedlings and leaves of adult plants, while the greatest change in total soluble protein pattern was observed in plant roots. Differences between control and treated tobacco tissues were more pronounced in the glycoprotein pattern, which was analysed by application of different lectins. The majority of the detected glycoproteins in leaves and roots of adult plants can be considered as a result of enhanced glycosylation due to heavy metal stress. The difference in glycoproteins between $\mathrm{Cd}$ and $\mathrm{Zn}$ application on tobacco seedlings and adult plants could not be determined since enhanced glycosylation was noticed after treatment with either metal alone or in combination. Therefore, it can be concluded that both metals induced N- and Oglycosylation as a result of changed environmental conditions.
\end{abstract}

KEY WORDS: heavy metals, lectins, protein pattern

Agricultural plants face a variety of abiotic and biotic stresses, which are major causes limiting crop production. Among abiotic stressors, heavy metal contamination represents a global environmental problem endangering humans, animals, and plants. Cadmium (Cd) is very toxic and without any metabolic significance (1). It is especially dangerous due to its long biological half-life. When released into the environment, $\mathrm{Cd}$ becomes accessible to plants, where its toxic effects involve a decrease in chlorophyll and carotenoid content, as well as changes in photosynthetic activity (2), growth inhibition and root damage (1), reduction of water and nutrient uptake (3), lipid peroxidation (4) and protein degradation $(1,5)$.
Toxicological properties of $\mathrm{Cd}$ originate from its chemical similarity to zinc ( $\mathrm{Zn})$, an essential micronutrient of great chemical and metabolic significance in plant systems (6). Zn plays a fundamental role in several cellular functions such as protein metabolism, gene expression, chromatin structure, photosynthetic carbon metabolism, and indole acetic acid metabolism (7) and is involved in the catalytic function of many enzymes and structural stability of various cell proteins (8). Cd frequently accompanies $\mathrm{Zn}$ minerals in the environment (9), which is why they have often been investigated together for their mutual effect on different plants. Up to this moment, mostly antagonistic interaction was suggested; it has been 
found that $\mathrm{Zn}$ can lessen physiological damage caused by $\mathrm{Cd}(10)$, suppress Cd uptake (6), and decrease Cdinduced oxidative stress (11).

It has been documented that exposure to heavy metals can cause changes in the expression of cellular plant proteins $(12,13)$. Some heavy metals, such as manganese $(\mathrm{Mn})$ and $\mathrm{Zn}$, stimulate protein synthesis (14), while other metabolites, such as $\mathrm{Cd}$, interfere with this process (15). Sobkowiak and Deckert(16) reported that $\mathrm{Cd}$ induced changes in the protein pattern in soybean cell suspension culture. Moreover, dramatic changes in the protein pattern of barley seedlings exposed to Cd were revealed by SDS-PAGE (17), while a proteomic approach has been adopted for the analysis of protein profile alternations during the germination of rice following exposure to $\mathrm{Cd}(18)$.

Posttranslational modifications such as glycosylation are important for altering the properties and functions of proteins. The oligosaccharide chain can be either $\mathrm{N}$ - or O-linked. N-glycosylation occurs in the endoplasmic reticulum (ER) and the primary oligosaccharide chain is further processed when it exits the ER and passes through the Golgi apparatus (GA). The latter cell compartment is also a site of protein O-glycosylation. Glycosylation can change basic biological functions of a protein including immunogenicity, specific activity, and the ligandreceptor interaction. Only few studies have been conducted on plants to reveal whether environmental conditions act upon protein glycosylation. The analysis of N-linked glycans of soluble endogenous glycoproteins from the leaves of tobacco demonstrated that developmental processes and different growth conditions could influence glycosylation $(19,20)$. It was found that N-glycosylation of extracellular (21$23)$ as well as cellular proteins $(22,24-27)$ was affected by in vitro culture conditions. However, modest information about the abiotic stress related to glycoprotein patterns is available so far. It has been revealed that the mutation in STT3 gene, which encodes important subunits of the enzyme oligosaccharyltransferase involved in protein $\mathrm{N}$ glycosylation, increases the sensibility to salt and osmotic stress (28). Moreover, Kang et al. (29) found that salt tolerance of Arabidopsis thaliana requires of N-glycosylated proteins to mature in the GA. In the basal parts of rice leaf sheaths, cold stress altered the glycosylation profile of calreticulin, a key protein that regulates the quality control of other proteins (30). Carpena et al. (31) suggested that glycoprotein accumulation might be considered as a useful indicator of Cd-induced stress in white lupin nodules. In a recent publication Zhang et al. (32) suggest that protein $\mathrm{N}$-glycoslyation might have a key role in plant development and abiotic stress response. The role of O-glycosylation in plant cells grown in a stressful environment is even less studied than $\mathrm{N}$-glycosylation. The report by Johnson et al. (33) indicates that arabinogalactans, a group of plant specific O-glycoslyated proteins, are likely to be important during plant development and in response to abiotic stress.

Tobacco, Nicotiana tabacum L., became a model plant in many studies due to its relative tolerance to environmental stress and wide distribution (34). All of the first achievements in plant genetic engineering are mostly based on the work with tobacco. This plant has been employed in studies on the production of useful recombinant proteins and antibodies, which have an application in medicine and industry (35). Moreover, tobacco has been found to be an extremely versatile system for all aspects of abiotic stress research, including the studies of physiological mechanisms, which lead to adverse environmental conditions $(36,37)$.

The aim of the present work was to investigate the effects of $\mathrm{Cd}$ and $\mathrm{Zn}$, applied separately or in combinations, on protein and glycoprotein patterns of soluble cellular proteins in seedlings and adult plants of tobacco.

\section{MATERIALS AND METHODS}

\section{Chemicals and instrumentation}

$\mathrm{CdCl}_{2}, \mathrm{ZnCl}_{2}, \mathrm{AgNO}_{3}$, glycine, sucrose, ascorbic acid, methanol, $\mathrm{HCl}$ and $\mathrm{NaCl}$ were obtained from Kemika (Zagreb, Croatia), while polyvinylpyrrolidone (PVP), bovine serum albumin (BSA), Tris, Phytagel, Tween ${ }^{\circledR}$ 20, EDTA, Con A, 4-chloro-1-naphthol and peroxidase were purchased from Sigma (Steinheim, Germany). Distilled and deionized water from MilliQ water systems (Millipore, Bedford, MA, USA) was used to prepare the nutrient media and extraction buffers. UV-VIS spectrophotometer ATI/Unicam UV4-100, (Cambridge, UK) was used to determine the protein concentration in extracts. Pure nitrocellulose membrane $-0.45 \mathrm{~mm}$ as well as electrophoresis system for protein separation and electroblotting (Mini-PROTEAN 3 Cell and Mini Trans-Blot Cell) 
were purchased from Bio-Rad (Bio-Rad Laboratories GmbH München, Germany). Protein Molecular Weight Marker was obtained from Fermentas (St. Leon-Rot, Germany). Ponceau-S stain and digoxigeninlabeled lectins GNA, DSA, PNA MAA, and SNA (their descriptions are given in Table 1) (DIG Glycan Differentiation Kit) were obtained from Roche Applied Science (Mannheim, Germany). Gels and membranes were scanned using HP Scanjet 2400 scanner (Hewlett-Packard Company, USA).

\section{Plant material and heavy metal treatments}

Seeds of Nicotiana tabacum L. cv Burley were surface sterilised with $50 \% \mathrm{NaOCl}$, washed with distilled $\mathrm{H}_{2} \mathrm{O}$ several times and subsequently germinated in sterilised nutrient medium. The medium was prepared according to Murashige and Skoog (38) with addition of the $500 \mathrm{mg} \mathrm{L}^{-1}$ MES [2(N-morpholino)ethanesulfonic acid], $1.5 \mathrm{~g} \mathrm{~L}^{-1}$ sucrose, and $2.2 \mathrm{~g} \mathrm{~L}^{-1}$ Phytagel (pH 5.6) (39) at $24^{\circ} \mathrm{C}$ with $16 \mathrm{~h}: 8 \mathrm{~h} \mathrm{light/dark} \mathrm{cycle} \mathrm{and} \mathrm{light} \mathrm{intensity} \mathrm{of}$ $90 \mu \mathrm{E} \mathrm{m}^{-2} \mathrm{~s}^{-1}$. In these conditions seedlings were grown for 90 days until adult plants were obtained.

For heavy metal treatment of seedlings, tobacco seeds were germinated for 30 days on solid MS nutrient medium with the addition of $\mathrm{Cd}, \mathrm{Zn}$ or their combinations. Cd treatments in concentrations of 10 $\mu \mathrm{mol} \mathrm{L}{ }^{-1}$ and $15 \mu \mathrm{mol} \mathrm{L}^{-1}$ were prepared by adding a stock solution of $\mathrm{CdCl}_{2}$ to the nutrient medium. $\mathrm{Zn}$ was added as $\mathrm{ZnCl}_{2}$ to the nutrient medium in the amounts suitable to achieve concentrations of $25 \mu \mathrm{mol} \mathrm{L}-1$ and $50 \mu \mathrm{mol} \mathrm{L}^{-1}$. Tobacco seedlings were also exposed to the combinations of metals $(10 \mu \mathrm{mol}$ $\mathrm{L}^{-1}$ or $15 \mu \mathrm{mol} \mathrm{L}-1 \mathrm{Cd}^{-}$with $25 \mu \mathrm{mol} \mathrm{L}-1$ and $50 \mu \mathrm{mol}$ $\mathrm{L}^{-1} \mathrm{Zn}$ ). For protein extraction, whole tobacco seedlings were used.
For exposure to heavy metals, adult plants obtained on the solid MS medium were transferred to the liquid medium of the same composition but with the addition of either metal alone $(10 \mu \mathrm{mol}$ $\mathrm{L}^{-1}$ or $15 \mu \mathrm{mol} \mathrm{L}^{-1} \mathrm{Cd}$ and $25 \mu \mathrm{mol} \mathrm{L}{ }^{-1}$ or $50 \mu \mathrm{mol} \mathrm{L}^{-1}$ $\mathrm{Zn})$ or their combinations $\left(10 \mu \mathrm{mol} \mathrm{L}^{-1}\right.$ or $15 \mu \mathrm{mol} \mathrm{L}^{-1}$ $\mathrm{Cd}$ with $25 \mu \mathrm{mol} \mathrm{L} \mathrm{L}^{-1}$ and $50 \mu \mathrm{mol} \mathrm{L}^{-1} \mathrm{Zn}$ ) and then treated for 7 days. For protein and glycoprotein pattern analyses, leaves and roots were analysed separately.

\section{Protein extracts, SDS-PAGE and electroblotting}

Total soluble proteins from tobacco seedlings were extracted by grinding $0.4 \mathrm{~g}$ of fresh tissues in $1.5 \mathrm{~mL}$ of $0.1 \mathrm{~mol} \mathrm{~L}^{-1}$ Tris/ $\mathrm{HCl}$ buffer, $\mathrm{pH} 8.0$ at $4{ }^{\circ} \mathrm{C}$ containing $17.1 \%$ sucrose, $0.1 \%$ ascorbic acid, $0.1 \%$ cystein (40), and (10 to 15$) \mathrm{mg}$ of PVP. For the extraction of total soluble proteins from leaves and roots of adult plants, $0.4 \mathrm{~g}$ of fresh tissue was homogenized in $1.0 \mathrm{~mL}$ cold $(0$ to 4$){ }^{\circ} \mathrm{C}$ extraction buffer (pH 7.5) containing $30 \mathrm{mmol} \mathrm{L}^{-1}$ Tris/ $\mathrm{HCl}$, $5 \mathrm{mmol} \mathrm{L}^{-1}$ EDTA, $20 \mathrm{mmol} \mathrm{L}^{-1} \mathrm{NaCl}$, and (10 to 15) $\mathrm{mg}$ of PVP. Homogenates were centrifuged at $20,000 \mathrm{xg}$ and $4{ }^{\circ} \mathrm{C}$ for $15 \mathrm{~min}$. Supernatants were centrifuged again at $20,000 \mathrm{xg}$ and $4{ }^{\circ} \mathrm{C}$ for $60 \mathrm{~min}$. The supernatant was collected and protein content was determined according to Bradford (41) using BSA as a standard. Obtained supernatants were used for the analysis of total soluble proteins and glycoproteins.

Total soluble proteins were analysed by SDSPAGE in $8 \%$ to $18 \% \mathrm{~T}(2.67 \% \mathrm{C})$ gradient gels, with the buffer system of Laemmli (42). For the SDSPAGE, the same amount of protein $(10 \mu \mathrm{g})$ per sample was loaded. Proteins migrated through stacking and separating gels at $100 \mathrm{~V}$ and $200 \mathrm{~V}$, respectively. Protein bands were visualised by silver staining (43) and gels were scanned as an 8 bit grey scale Tiffimages.

Table 1 Major $N$ - and O-linked carbohydrate binding specificities of different plant lectins applied.

\begin{tabular}{lccc}
\hline Lectin & $\begin{array}{c}\text { Taxonomic lectin } \\
\text { source }\end{array}$ & $\begin{array}{c}\text { Specificity toward } \\
\text { carbohydrate moieties }\end{array}$ & Type of glycans \\
\hline Con A & Canavalia ensiformis & $\begin{array}{c}\alpha \text {-D-Glu } \\
\text {-D-Man }\end{array}$ & core N-glycan structure (44) \\
\hline GNA & Galanthus nivalis & $\alpha$-D-Man & high-mannose N-glycans (44) \\
\hline PNA & Arachis hypogaea & $\beta$-Gal-(1,3)-GalNAc & O-glycosidically linked carbohydrates (45) \\
\hline DSA & Datura stramonium & Gal- $(1,4)-G l c N A c$ & complex and hybrid N-glycans (46) \\
\hline MAA & Maackia amurensis & NeuAc- $\alpha(2,3)-G a l$ & sialic acid in complex N- and O-glycans (47) \\
\hline SNA & Sambucus nigra & NeuAc- $\alpha(2,6)-G a l$ & sialic acid in complex N- and O-glycans $(47)$ \\
\hline
\end{tabular}


For lectin assays, proteins were separated by SDSPAGE in $12 \% \mathrm{~T}(2.67 \% \mathrm{C})$ polyacrylamide gels (42). The same amount of protein $(15 \mu \mathrm{g})$ per sample was loaded. Proteins migrated through stacking and separating gels at $100 \mathrm{~V}$ and $200 \mathrm{~V}$, respectively. Subsequently, proteins were electroblotted to the nitrocellulose membrane in a mini trans-blot cell at $60 \mathrm{~V}$ for $60 \mathrm{~min}$. The transfer buffer was $20 \mathrm{mmol}$ $\mathrm{L}^{-1}$ Tris- $\mathrm{HCl}, 150 \mathrm{mmol} \mathrm{L}^{-1}$ glycine and $10 \%$ methanol. The membrane was stained with Ponceau$\mathrm{S}$ stain to confirm the complete transfer of proteins. The stain was washed off with distilled water. The unoccupied sites of the membrane were blocked by incubating the membrane with $0.1 \%$ Tween ${ }^{\circledR} 20$ in TBS buffer, $\mathrm{pH} 7.5$ at $4{ }^{\circ} \mathrm{C}$ overnight. Glycoproteins with D-manose in their glycan component were detected on nitrocellulose membrane by the reaction with Con A. Bands were visualised by peroxidase reaction using 4-chloro-1-naphthol as a substrate (44). The glycan part of proteins was further characterised according to binding of digoxigenin-labelled lectins GNA(45), DSA (46), PNA (46), MAA (47), and SNA (47) (Table1). The staining procedure was performed following the manufacturer's instructions. Membranes were scanned as an 8 bit grey scale Tiff-images.

\section{RESULTS}

\section{Total soluble cell proteins}

We observed changes in only few polypeptides related to heavy metal treatments in tobacco seedlings (Figure 1): protein band of $116 \mathrm{kDa}$ (arrows) was present in all samples, although with weaker intensity in the control and treatments with lower concentration of both metals, $10 \mu \mathrm{mol} \mathrm{L}^{-1} \mathrm{Cd}$ and $25 \mu \mathrm{mol} \mathrm{L}^{-1} \mathrm{Zn}$. Moreover, seedlings exposed separately to $10 \mu \mathrm{mol}$ $\mathrm{L}^{-1} \mathrm{Cd}$ and $25 \mu \mathrm{mol} \mathrm{L}^{-1} \mathrm{Zn}$ exhibited weak expression of $118 \mathrm{kDa}$ protein (star) in comparison with other treatments, while the $56 \mathrm{kDa}$ (black circle) was missing after the combined treatments with $10 \mu \mathrm{mol}$ $\mathrm{L}^{-1} \mathrm{Cd}$ and $25 \mu \mathrm{mol} \mathrm{L}{ }^{-1} \mathrm{Zn}$ as well as with $15 \mu \mathrm{mol}$ $\mathrm{L}^{-1} \mathrm{Cd}$ and $50 \mu \mathrm{mol} \mathrm{L}-1 \mathrm{Zn}$. $25 \mathrm{kDa}$ protein (white circles) was missing after the treatment with $50 \mu \mathrm{mol} \mathrm{L}^{-1} \mathrm{Zn}$ as well as with combinations of $10 \mu \mathrm{mol} \mathrm{L}{ }^{-1} \mathrm{Cd}$ and both concentrations of $\mathrm{Zn}$.

In tobacco leaves, a protein of $120 \mathrm{kDa}$ (arrows) was expressed after exposure of adult plants to $10 \mu \mathrm{mol} \mathrm{L}{ }^{-1} \mathrm{Cd}$, both $\mathrm{Zn}$ concentrations, and combined

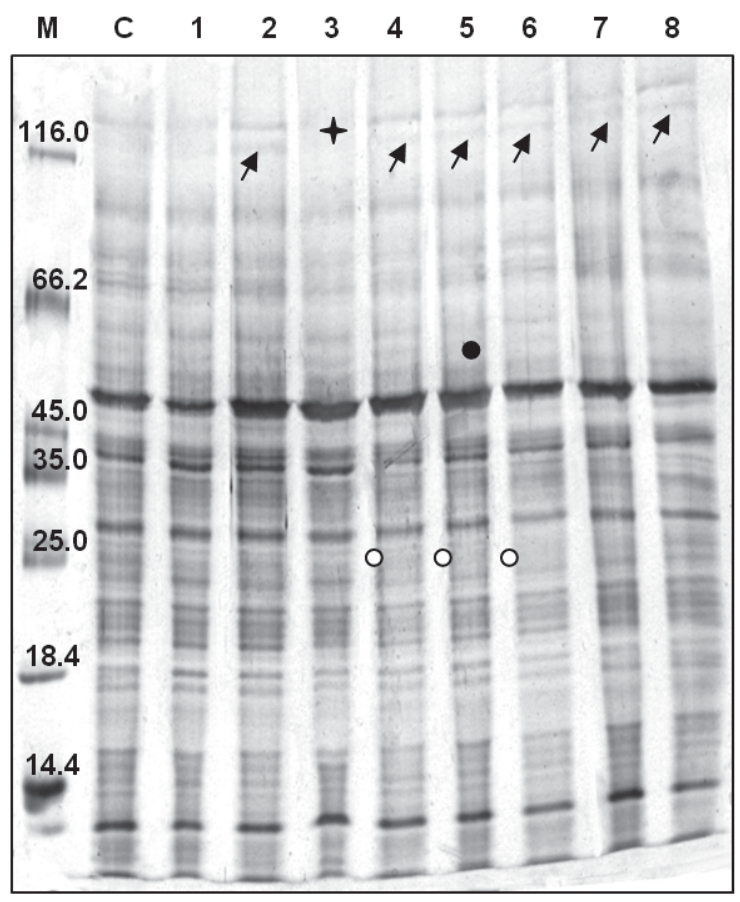

Figure 1 Total soluble cell proteins of tobacco seedlings separated by SDS-PAGE in gradient $8 \%$ to $18 \%$ gel and silver stained. $M$ - protein molecular weight marker, $C$ - control; (1 to 10) $\mu \mathrm{mol} \mathrm{L} \mathrm{L}^{-1} \mathrm{Cd}$; (2 to 15) $\mu \mathrm{mol} \mathrm{L} L^{-1} \mathrm{Cd}$; (3 to 25) $\mu \mathrm{mol} \mathrm{L} \mathrm{L}^{-1} \mathrm{Zn}$; (4 to 50) $\mu \mathrm{mol} \mathrm{L} \mathrm{L}^{-1} \mathrm{Zn}$; (5 to 10) $\mu \mathrm{mol} \mathrm{L}^{-1} \mathrm{Cd}$ and $25 \mu \mathrm{mol}$ $L^{-1} \mathrm{Zn}$; (6 to 10) $\mu \mathrm{mol} \mathrm{L} L^{-1} \mathrm{Cd}$ and $50 \mu \mathrm{mol} \mathrm{L} \mathrm{L}^{-1} \mathrm{Zn}$; (7 to 15$) \mu \mathrm{mol} \mathrm{L} L^{-1} \mathrm{Cd}$ and $25 \mu \mathrm{mol} L^{-1} \mathrm{Zn}$; $(8$ to 15) $\mu \mathrm{mol} \mathrm{L} \mathrm{L}^{-1} \mathrm{Cd}$ and $50 \mu \mathrm{mol} \mathrm{L}^{-1} \mathrm{Zn}$.

treatments with both $\mathrm{Cd}$ concentrations and $50 \mu \mathrm{mol}$ $\mathrm{L}^{-1} \mathrm{Zn}$ (Figure 2A). The $60 \mathrm{kDa}$ polypeptide (star) was specific for combined treatments of $15 \mu \mathrm{mol} \mathrm{L}^{-1} \mathrm{Cd}$ with 25 and $50 \mu \mathrm{mol} \mathrm{L}^{-1} \mathrm{Zn}$. In comparison to control, all leaves from treated plants exhibited a stronger expression of $45 \mathrm{kDa}, 50 \mathrm{kDa}$ and $55 \mathrm{kDa}$ proteins (black circles).

The greatest change in total soluble protein pattern was observed in roots of adult plants (Figure 2B). The $20 \mathrm{kDa}$ and $25 \mathrm{kDa}$ proteins had a stronger expression in control in comparison with treated roots (stars). After the exposure to $50 \mu \mathrm{mol} \mathrm{L}^{-1} \mathrm{Zn}$, protein bands of $50 \mathrm{kDa}, 70 \mathrm{kDa}$ and $116 \mathrm{kDa}$ (black circles) were observed in roots of adult plants with the strongest staining intensity. The $45 \mathrm{kDa}$ proteins (black squares) were expressed after the treatment with $15 \mu \mathrm{mol} \mathrm{L}-1$ $\mathrm{Cd}, 25 \mu \mathrm{mol} \mathrm{L}^{-1} \mathrm{Zn}$ as well as in combined treatment with $15 \mu \mathrm{mol} \mathrm{L}^{-1} \mathrm{Cd}$ and $50 \mu \mathrm{mol} \mathrm{L}^{-1} \mathrm{Zn}$, although they were present as very faint bands in combined treatments with $10 \mu \mathrm{mol} \mathrm{L}^{-1} \mathrm{Cd}$ and $50 \mu \mathrm{mol} \mathrm{L}^{-1} \mathrm{Zn}$ as well as $15 \mu \mathrm{mol} \mathrm{L}{ }^{-1} \mathrm{Cd}_{\text {and }} 25 \mu \mathrm{mol} \mathrm{\textrm {L } ^ { - 1 }} \mathrm{Zn}$. Roots treated with $15 \mu \mathrm{mol} \mathrm{L}{ }^{-1} \mathrm{Cd}$ in combination with both 

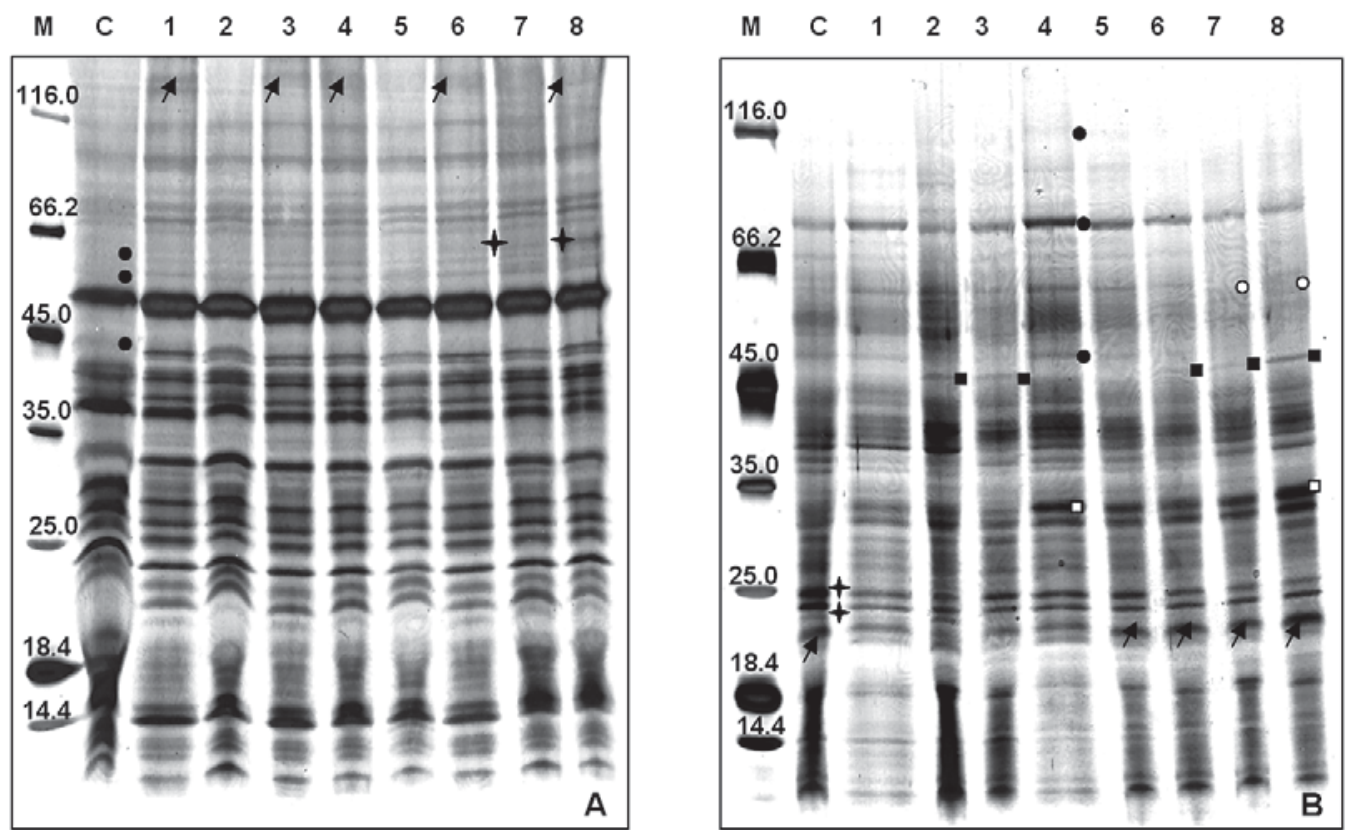

Figure 2 Total soluble cell proteins of A) leaves and B) roots of adult tobacco plants separated by SDS-PAGE in gradient $8 \%$ to $18 \% \mathrm{gel}$ and silver stained. For lane labels see Figure 1.

$\mathrm{Zn}$ concentrations were devoid of the $60 \mathrm{kDa}$ protein (white circles). Protein band of $30 \mathrm{kDa}$ (white squares) had a stronger expression after the treatment with $50 \mu \mathrm{mol} \mathrm{L}^{-1} \mathrm{Zn}$ alone and in combination with $15 \mu \mathrm{mol} \mathrm{L}-1 \mathrm{Cd}^{-1}$ comparison with other treatments, while the $20 \mathrm{kDa}$ polypeptide (arrows) was more pronounced in control roots and those exposed to combinations of metals compared to each metal alone.

\section{Glycoproteins}

In control and in treated seedlings, the $45 \mathrm{kDa}$ glycoprotein (black frame) was detected, although in the treatment with $15 \mu \mathrm{mol} \mathrm{L}{ }^{-1} \mathrm{Cd}$ and $50 \mu \mathrm{mol} \mathrm{L}^{-1} \mathrm{Zn}$ was present as a very faint band (Figure $3 \mathrm{~A}$ ). The $50 \mathrm{kDa}$ glycoprotein (grey frame) was revealed in all samples, except in combined treatment with $15 \mu \mathrm{mol} \mathrm{L}^{-1}$ $\mathrm{Cd}$ and $50 \mu \mathrm{mol} \mathrm{L}^{-1} \mathrm{Zn}$. Control leaves and those treated with $10 \mu \mathrm{mol} \mathrm{L}^{-1} \mathrm{Cd}$ and $50 \mu \mathrm{mol} \mathrm{L}^{-1} \mathrm{Zn}$ alone and with combination of $10 \mu \mathrm{mol} \mathrm{L}^{-1} \mathrm{Cd}$ and 50 $\mu \mathrm{mol} \mathrm{L}{ }^{-1} \mathrm{Zn}$, as well as $15 \mu \mathrm{mol} \mathrm{L}{ }^{-1} \mathrm{Cd}$ with $25 \mu \mathrm{mol}$ $\mathrm{L}^{-1} \mathrm{Zn}$ were characterised by the $35 \mathrm{kDa}$ band (dashed frame). GNA revealed glycoproteins of $40 \mathrm{kDa}$ (white circle) and $43 \mathrm{kDa}$ (black circle) of the strongest staining intensity (Figure 3B), which were present in control and all treatments, except in combined treatment with $15 \mu \mathrm{mol} \mathrm{L}^{-1} \mathrm{Cd}$ and $50 \mu \mathrm{mol} \mathrm{L}^{-1} \mathrm{Zn}$. Glycoproteins of $46 \mathrm{kDa}$ (grey arrow) and $50 \mathrm{kDa}$ (black arrow) were detected as very faint bands and were more pronounced in treatments with either metal alone than in combined treatments. The $20 \mathrm{kDa}$ glycoprotein (star) was detected in control seedlings as well as in those treated with $10 \mu \mathrm{mol} \mathrm{L}^{-1} \mathrm{Cd}$, $50 \mu \mathrm{mol} \mathrm{L}^{-1} \mathrm{Zn}, 15 \mu \mathrm{mol} \mathrm{L}^{-1} \mathrm{Cd}$ and $25 \mu \mathrm{mol} \mathrm{L}^{-1} \mathrm{Zn}$, as well as $10 \mu \mathrm{mol} \mathrm{L}^{-1} \mathrm{Cd}$ and $50 \mu \mathrm{mol} \mathrm{L}^{-1} \mathrm{Zn}$. Exposure to $50 \mu \mathrm{mol} \mathrm{L}^{-1} \mathrm{Zn}$ resulted in the appearance of $15 \mathrm{kDa}, 16 \mathrm{kDa}$ and $17 \mathrm{kDa}$ bands (asterisks), which were also detected in treatments with $10 \mu \mathrm{mol} \mathrm{L}^{-1} \mathrm{Cd}$ and $50 \mu \mathrm{mol} \mathrm{L}^{-1} \mathrm{Zn}$ as well as with $15 \mu \mathrm{mol} \mathrm{L}^{-1} \mathrm{Cd}$ and $25 \mu \mathrm{mol} \mathrm{L}^{-1} \mathrm{Zn}$, but with weaker expression. In control and in treated seedlings, PNA revealed the $43 \mathrm{kDa}$ glycoprotein (black arrow), whose expression was the strongest after treatment with $50 \mu \mathrm{mol} \mathrm{L}^{-1} \mathrm{Zn}$ (Figure 3C). Combined treatment with $15 \mu \mathrm{mol} \mathrm{L}^{-1}$ $\mathrm{Cd}$ and $50 \mu \mathrm{mol} \mathrm{L}^{-1} \mathrm{Zn}$ was devoid of the $38 \mathrm{kDa}$ band (grey arrow), whose expression was the strongest in the treatment with $50 \mu \mathrm{mol} \mathrm{L}^{-1} \mathrm{Cd}$. Control seedlings and those exposed to $50 \mu \mathrm{mol} \mathrm{L}^{-1} \mathrm{Zn}$ and combinations of $10 \mu \mathrm{mol} \mathrm{L}^{-1} \mathrm{Cd}^{-1}$ and $50 \mu \mathrm{mol} \mathrm{L}^{-1} \mathrm{Zn}$ as well as $15 \mu \mathrm{mol} \mathrm{L}-1 \mathrm{Cd}^{-1}$ and $25 \mu \mathrm{mol} \mathrm{L}^{-1} \mathrm{Zn}$, were characterised by the presence of the $18 \mathrm{kDa}$ glycoprotein (black circle). In the above mentioned treatments $17 \mathrm{kDa}$ band was detected (star), while the exposure to $50 \mu \mathrm{mol} \mathrm{L}^{-1} \mathrm{Zn}$ and to a combination of $15 \mu \mathrm{mol} \mathrm{L}^{-1}$ $\mathrm{Cd}$ and $25 \mu \mathrm{mol} \mathrm{L}^{-1} \mathrm{Zn}$ resulted in the appearance of the $16 \mathrm{kDa}$ glycoprotein (asterisk). DSA revealed only 
two glycoproteins (Figure 3D). The $43 \mathrm{kDa}$ one (black arrow) was missing from the treatments with $15 \mu \mathrm{mol} \mathrm{L}^{-1} \mathrm{Cd}, 25 \mu \mathrm{mol} \mathrm{L}^{-1} \mathrm{Zn}$ as well as from combined treatment with $15 \mu \mathrm{mol} \mathrm{L}^{-1} \mathrm{Cd}$ and $50 \mu \mathrm{mol} \mathrm{L}^{-1} \mathrm{Zn}$. Exposure to $50 \mu \mathrm{mol} \mathrm{L}^{-1} \mathrm{Zn}$ alone and to combinations of $10 \mu \mathrm{mol} \mathrm{L}^{-1} \mathrm{Cd}$ and $50 \mu \mathrm{mol} \mathrm{L}^{-1}$ $\mathrm{Zn}$ as well as $15 \mu \mathrm{mol} \mathrm{L} \mathrm{L}^{-1} \mathrm{Cd}$ and $25 \mu \mathrm{mol} \mathrm{L}^{-1} \mathrm{Zn}$ resulted in the appearance of the $38 \mathrm{kDa}$ glycoprotein (grey arrow). Nine glycosylated proteins were detected in seedlings with MAA(Figure 3E). The $43 \mathrm{kDa}$ (black arrow) and $45 \mathrm{kDa}$ (grey arrow) glycoproteins were present in control and all treatments as very strong bands, while the $66 \mathrm{kDa}$ (black circle) and $68 \mathrm{kDa}$ (white circle) ones were visible as proteins with weak staining intensity. Seedlings exposed to $10 \mu \mathrm{mol} \mathrm{L}^{-1}$

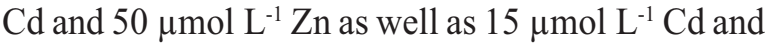
$25 \mu \mathrm{mol} \mathrm{L}^{-1} \mathrm{Zn}$ were characterised by the presence of the $55 \mathrm{kDa}$ glycoprotein (star), which was also detected as a very faint band in control seedlings and in those treated with single $10 \mu \mathrm{mol} \mathrm{L}^{-1} \mathrm{Cd}$ and $50 \mu \mathrm{mol} \mathrm{L}^{-1} \mathrm{Zn}$. The $22 \mathrm{kDa}$ band (asterisk) was present in treatments with $50 \mu \mathrm{mol} \mathrm{L}^{-1} \mathrm{Zn}$ as well as with $15 \mu \mathrm{mol} \mathrm{L} \mathrm{L}^{-1} \mathrm{Cd}$ and $25 \mu \mathrm{mol} \mathrm{L}^{-1} \mathrm{Zn}$, while the $20 \mathrm{kDa}$ one (white star) was detected in control and in treatments with $10 \mu \mathrm{mol} \mathrm{L}^{-1} \mathrm{Cd}, 50 \mu \mathrm{mol} \mathrm{L}^{-1} \mathrm{Zn}$, $10 \mu \mathrm{mol} \mathrm{L}^{-1} \mathrm{Cd}$ and $50 \mu \mathrm{mol} \mathrm{L}^{-1} \mathrm{Zn}$ as well as $15 \mu \mathrm{mol} \mathrm{L}^{-1} \mathrm{Cd}$ and $25 \mu \mathrm{mol} \mathrm{L}^{-1} \mathrm{Zn}$. Combined treatment with $15 \mu \mathrm{mol} \mathrm{L}-10 \mathrm{Cd}$ and $25 \mu \mathrm{mol} \mathrm{L} \mathrm{L}^{-1} \mathrm{Zn}$ revealed the $16 \mathrm{kDa}$ (white square) and $17 \mathrm{kDa}$ (black square) glycoproteins. SNA revealed the $35 \mathrm{kDa}$ glycoprotein (black arrow) in control and all treatments except for the combined treatment with $15 \mu \mathrm{mol} \mathrm{L}{ }^{-1}$ $\mathrm{Cd}$ and $50 \mu \mathrm{mol} \mathrm{L}^{-1} \mathrm{Zn}$ (Figure 3F). Glycosylated protein of $32 \mathrm{kDa}$ (grey arrow) was missing from the
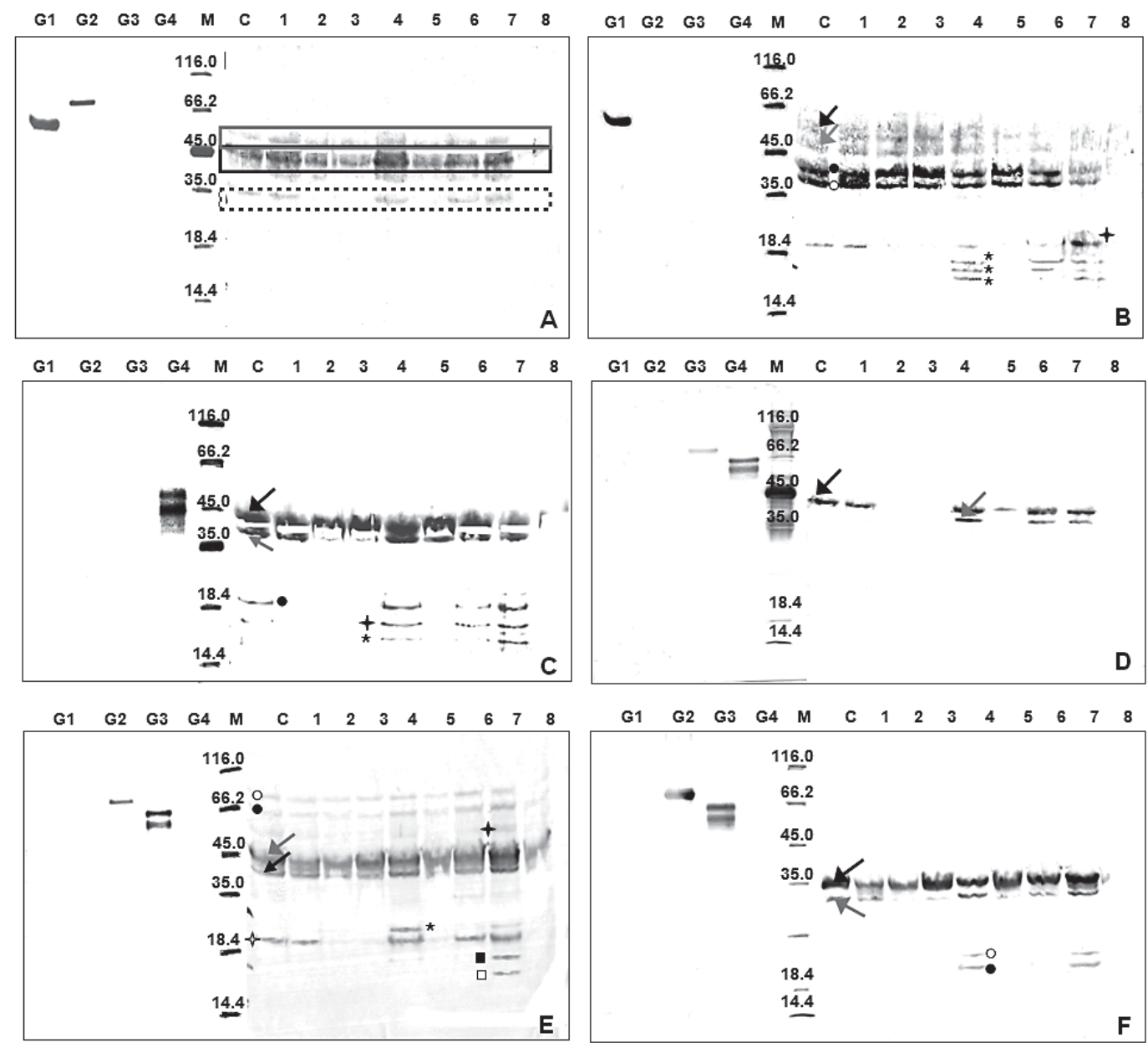

Figure 3 Glycoprotein pattern of tobacco seedlings detected by lectins A) Con A, B) GNA, C) PNA, D) DSA, E) MAA, and F) SNA. G1 - control glycoprotein carboxypeptidase Y (positive control for Con A and GNA), G2 - control glycoprotein transferrin (positive control for MAA and SNA), G3 - fetuin (positive control for DSA, MAA and SNA), G4 - asialofetuin (positive control for DSA and PNA). For lane labels see Figure 1 
treatment with $15 \mu \mathrm{mol} \mathrm{L}-1 \mathrm{Cd}^{-1}$ as well as with $15 \mu \mathrm{mol} \mathrm{L}{ }^{-1} \mathrm{Cd}$ and $50 \mu \mathrm{mol} \mathrm{L}^{-1} \mathrm{Zn}$. Very faint bands of $22 \mathrm{kDa}$ and $23 \mathrm{kDa}$ (black and white circle) were present only after exposure to $50 \mu \mathrm{mol} \mathrm{L}^{-1} \mathrm{Zn}$ and combination of $15 \mu \mathrm{mol} \mathrm{L}^{-1} \mathrm{Cd}$ and $25 \mu \mathrm{mol} \mathrm{L}^{-1} \mathrm{Zn}$.

Three glycosylated proteins were detected by Con A (Figure 4A), according to which all leaves of tobacco adult plants were characterised by the presence of $60 \mathrm{kDa}$ glycoprotein (grey frame), which was the most pronounced one. This glycoprotein band showed a stronger expression in all treatments in comparison to control. Control leaves and those treated with $15 \mu \mathrm{mol} \mathrm{L}^{-1} \mathrm{Cd}$ were devoid of the $43 \mathrm{kDa}$ (dashed frame) and $68 \mathrm{kDa}$ glycoprotein (black frame) of weaker staining intensities. The pattern of glycosylated proteins detected with GNA (Figure 4B) was very similar to that obtained with Con $\mathrm{A} ; 43 \mathrm{kDa}$ (grey arrow) and $60 \mathrm{kDa}$ glycoproteins (black arrow) were present in leaves of all treated plants, while they were missing in control plants. Moreover, GNA revealed two additional bands of very weak expression; $15 \mathrm{kDa}$ glycoprotein (black circle) was present in the treatment with $10 \mu \mathrm{mol} \mathrm{L}^{-1} \mathrm{Cd}$ and $50 \mu \mathrm{mol} \mathrm{L}^{-1} \mathrm{Zn}$, while the $20 \mathrm{kDa}$ (white circle) one was detected after exposure to $25 \mu \mathrm{mol} \mathrm{L}^{-1} \mathrm{Zn}$ and combined treatment with $10 \mu \mathrm{mol} \mathrm{L}^{-1} \mathrm{Cd}$ and $50 \mu \mathrm{mol} \mathrm{L}^{-1} \mathrm{Zn}$. PNA revealed the $40 \mathrm{kDa}$ protein (black arrow) of very strong expression in all treated samples except in control leaves (Figure 4C), while very faint band of $68 \mathrm{kDa}$ (grey arrow) was detected in leaves of plants exposed to single $10 \mu \mathrm{mol} \mathrm{L}-1$ Cd and $50 \mu \mathrm{mol} \mathrm{L}^{-1} \mathrm{Zn}$. Exposure to $10 \mu \mathrm{mol} \mathrm{L}^{-1} \mathrm{Cd}$ as well as to both concentrations of $\mathrm{Zn}$ alone resulted in very low expression of $35 \mathrm{kDa}$ glycoprotein (black circle). The $27 \mathrm{kDa}$ band (white circle) was missing from the control and treatments with $15 \mu \mathrm{mol} \mathrm{L}-1 \mathrm{Cd}^{-}$alone and
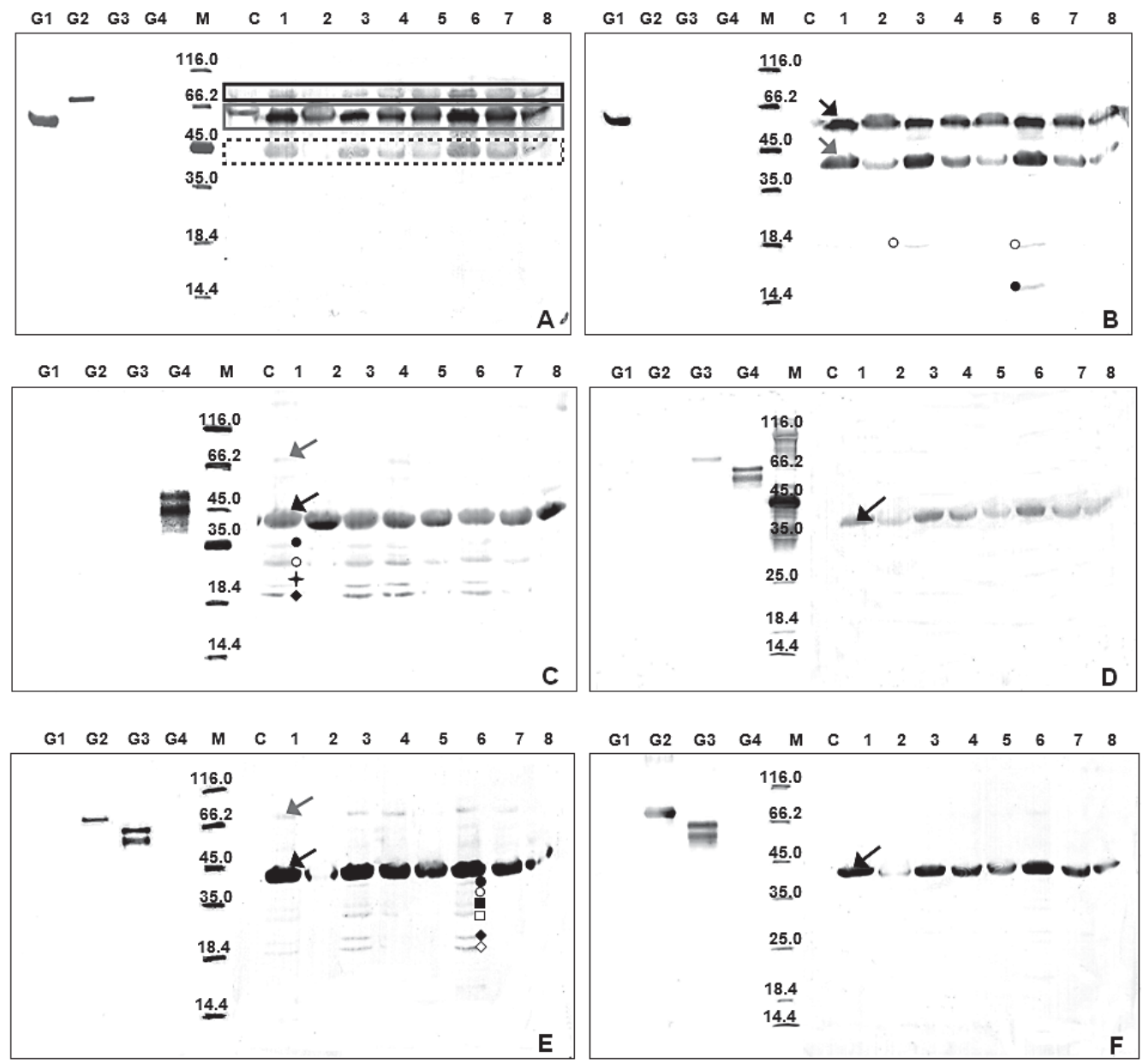

Figure 4 Glycoprotein pattern of leaves of adult tobacco plants detected by lectins A) Con A, B) GNA, C) PNA, D) DSA, E) $M A A$, and F) SNA. G1 - control glycoprotein carboxypeptidase $Y$ (positive control for Con A and GNA), G2 - control glycoprotein transferrin (positive control for MAA and SNA), G3 - fetuin (positive control for DSA, MAA and SNA), G4 - asialofetuin (positive control for DSA and PNA). For lane labels see Figure 1 
combination of $15 \mu \mathrm{mol} \mathrm{L} \mathrm{L}^{-1} \mathrm{Cd}$ and $50 \mu \mathrm{mol} \mathrm{L}-1 \mathrm{Zn}$, while the $20 \mathrm{kDa}$ (diamond) and $22 \mathrm{kDa}$ (star) ones were observed in treatments with single $10 \mu \mathrm{mol}$ $\mathrm{L}^{-1} \mathrm{Cd}, 25 \mu \mathrm{mol} \mathrm{L}-1$, and $50 \mu \mathrm{mol} \mathrm{L}^{-1} \mathrm{Zn}$ as well as in combined treatments of $10 \mu \mathrm{mol} \mathrm{L}^{-1} \mathrm{Cd}$ with $25 \mu \mathrm{mol} \mathrm{L}-1$, and $50 \mu \mathrm{mol} \mathrm{L}^{-1} \mathrm{Zn}$. Leaves from adult plants exposed to all investigated treatments revealed with DSA only one glycoprotein of $40 \mathrm{kDa}$ (black arrow), whose expression was the strongest in the treatments with single $10 \mu \mathrm{mol} \mathrm{L}^{-1} \mathrm{Cd}$ and $25 \mu \mathrm{mol}$ $\mathrm{L}^{-1} \mathrm{Zn}$ as well as in combined treatment with $10 \mu \mathrm{mol} \mathrm{L}^{-1} \mathrm{Cd}$ and $50 \mu \mathrm{mol} \mathrm{L}^{-1} \mathrm{Zn}$ (Figure 4D). Control leaves were devoid of any glycoproteins after the MAA was applied (Figure 4E). In total, eight bands were detected with this lectin in leaves of treated plants, among which the $43 \mathrm{kDa}$ one (black arrow) was present in all the treatments with the strongest staining intensity. The $70 \mathrm{kDa}$ protein (grey arrow) of the weaker expression was detected in all treatments except in the $15 \mu \mathrm{mol} \mathrm{L}^{-1} \mathrm{Cd}$ treatment and in combined treatments with $10 \mu \mathrm{mol} \mathrm{L}^{-1} \mathrm{Cd}$ and $25 \mu \mathrm{mol} \mathrm{L}^{-1} \mathrm{Zn}$ as well as $15 \mu \mathrm{mol} \mathrm{L}^{-1} \mathrm{Cd}$ and $50 \mu \mathrm{mol} \mathrm{L}^{-1} \mathrm{Zn}$. Very faint glycoproteins of $20 \mathrm{kDa}$ (white diamond), $22 \mathrm{kDa}$ (black diamond), $32 \mathrm{kDa}$ (white square), and $36 \mathrm{kDa}$ (black square) were detected after exposure to single $10 \mu \mathrm{mol} \mathrm{L}^{-1} \mathrm{Cd}$ and $25 \mu \mathrm{mol} \mathrm{L}^{-1} \mathrm{Zn}$ as well as to combined treatment with $10 \mu \mathrm{mol} \mathrm{L}-1 \mathrm{Cd}^{2}$ and $50 \mu \mathrm{mol} \mathrm{L}^{-1} \mathrm{Zn}$, while the $40 \mathrm{kDa}$ one (black circle) was present only in treatment with $25 \mu \mathrm{mol} \mathrm{L}{ }^{-1} \mathrm{Zn}$ alone as well as with combination of $10 \mu \mathrm{mol} \mathrm{L}^{-1} \mathrm{Cd}$ and $50 \mu \mathrm{mol} \mathrm{L}^{-1} \mathrm{Zn}$. Combined treatment of $10 \mu \mathrm{mol} \mathrm{L} \mathrm{L}^{-1} \mathrm{Cd}$ and $50 \mu \mathrm{mol} \mathrm{L} \mathrm{L}^{-1} \mathrm{Zn}$ was characterised by the presence of $38 \mathrm{kDa}$ glycosylated protein (white circle). After incubation with SNA,
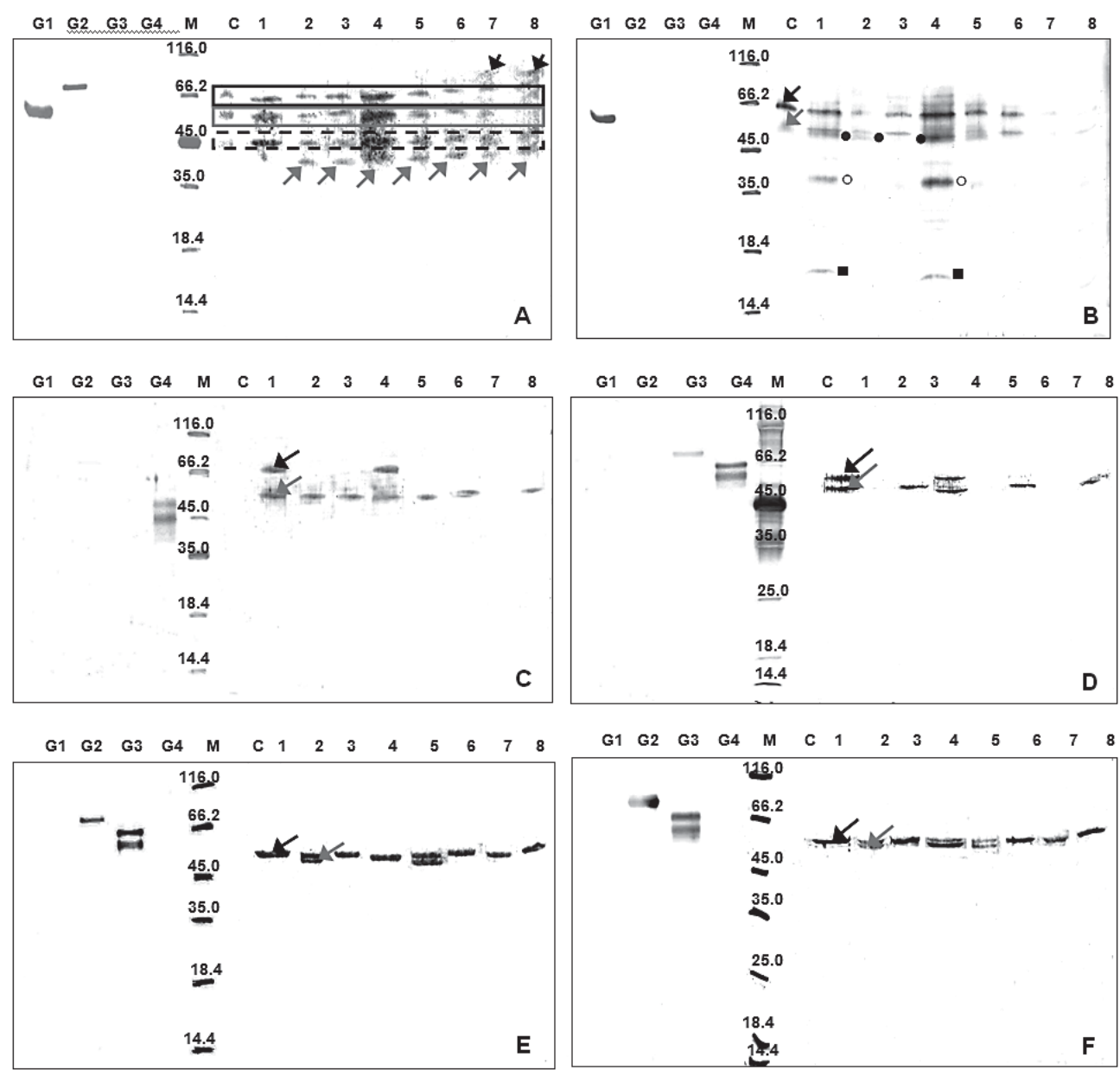

Figure 5 Glycoprotein pattern of roots of adult tobacco plants detected by lectins A) Con A, B) GNA, C) PNA, D) DSA, E) MAA, and F) SNA. G1 - control glycoprotein carboxypeptidase Y (positive control for Con A and GNA), G2 - control glycoprotein transferrin (positive control for MAA and SNA), G3 - fetuin (positive control for DSA, MAA and SNA), G4 - asialofetuin (positive control for DSA and PNA). For lane labels see Figure 1 
leaves from the treated plants revealed only one glycoprotein of $43 \mathrm{kDa}$ (black arrow), the expression of which was much weaker after exposure to $15 \mu \mathrm{mol} \mathrm{L}-1 \mathrm{Cd}^{-}$in comparison with other treatments (Figure 4F).

Roots of adult plants revealed in total five glycoprotein bands with Con A (Figure 5A). The $45 \mathrm{kDa}$ (dashed frame), $60 \mathrm{kDa}$ (grey frame), and $66 \mathrm{kDa}$ (black frame) glycoproteins were detected in control and all the treatments, although their expression was the strongest after exposure to $50 \mu \mathrm{mol} \mathrm{L}^{-1} \mathrm{Zn}$. Combined treatments with $15 \mu \mathrm{mol} \mathrm{L}^{-1} \mathrm{Cd}_{\text {and }}$ $25 \mu \mathrm{mol} \mathrm{L}^{-1} \mathrm{Zn}$ as well as $15 \mu \mathrm{mol} \mathrm{L}^{-1} \mathrm{Cd}$ and $50 \mu \mathrm{mol} \mathrm{L}^{-1} \mathrm{Zn}$ were characterised by the presence of $70 \mathrm{kDa}$ band (black arrow). The $43 \mathrm{kDa}$ glycoprotein (grey arrows) was detected in roots of adult plants exposed to single $15 \mu \mathrm{mol} \mathrm{L}^{-1} \mathrm{Cd}$ and to $\mathrm{Zn}$ at both concentrations as well as to all combined treatments, with the strongest staining intensity after exposure of single $50 \mu \mathrm{mol} \mathrm{L}^{-1} \mathrm{Zn}$. Five glycoprotein bands were detected in roots of adult plants with GNA (Figure 5B). The $50 \mathrm{kDa}$ (grey arrow) and $60 \mathrm{kDa}$ (black arrow) bands were present in control and all treatments except in the combined exposure to $15 \mu \mathrm{mol} \mathrm{L}^{-1} \mathrm{Cd}$ with $25 \mu \mathrm{mol} \mathrm{L}^{-1}$ or $50 \mu \mathrm{mol} \mathrm{L}-1 \mathrm{Zn}$. The treatments with single $\mathrm{Cd}$ at both concentrations as well as with $50 \mu \mathrm{mol} \mathrm{L}-1 \mathrm{Zn}$ were characterised by the presence of the $48 \mathrm{kDa}$ band (black circles). The $16 \mathrm{kDa}$ (black squares) and $40 \mathrm{kDa}$ (white circles) glycoproteins appeared in roots after exposure to single $10 \mu \mathrm{mol} \mathrm{L}$ ${ }^{1} \mathrm{Cd}$ and $50 \mu \mathrm{mol} \mathrm{L}{ }^{-1} \mathrm{Zn}$. Only roots of adult plants exposed to metal treatments revealed bands with PNA; the $66 \mathrm{kDa}$ band (black arrow) was detected in treatments with single $10 \mu \mathrm{mol} \mathrm{L}-1 \mathrm{Cd}^{-}$and $50 \mu \mathrm{mol}$ $\mathrm{L}^{-1} \mathrm{Zn}$, while the $50 \mathrm{kDa}$ one (grey arrow) was present in all treatments, except for the combination of $15 \mu \mathrm{mol} \mathrm{L}-1 \mathrm{Cd}^{-}$and $25 \mu \mathrm{mol} \mathrm{L}^{-1} \mathrm{Zn}$ (Figure 5C). DSA also reacted with root proteins of adult plants (Figure 5D). The $60 \mathrm{kDa}$ glycoprotein (black arrow) was detected after exposure to single $10 \mu \mathrm{mol} \mathrm{L}^{-1} \mathrm{Cd}$ and $50 \mu \mathrm{mol} \mathrm{L}^{-1} \mathrm{Zn}$, with stronger staining intensity in $\mathrm{Cd}$ treatment. The $10 \mu \mathrm{mol} \mathrm{L}^{-1} \mathrm{Cd}$ treatment gave strong expression of $50 \mathrm{kDa}$ band (grey arrow), while the same glycoprotein was also detected in treatments with single $\mathrm{Zn}$ at both concentrations and in combined treatments with $10 \mu \mathrm{mol} \mathrm{L}^{-1} \mathrm{Cd}$ and $50 \mu \mathrm{mol} \mathrm{L}^{-1} \mathrm{Zn}$ as well as $15 \mu \mathrm{mol} \mathrm{L}^{-1} \mathrm{Cd}$ and $50 \mu \mathrm{mol} \mathrm{L}^{-1} \mathrm{Zn}$. MAA (Figure 5E) and SNA (Figure 5F) lectins revealed two glycoprotein bands in roots of treated plants. All treatments were characterized by the presence of the $55 \mathrm{kDa}$ band (black arrow) with both lectins. The
$53 \mathrm{kDa}$ band (grey arrow) appeared in treatments with $15 \mu \mathrm{mol} \mathrm{L}^{-1} \mathrm{Cd}$ and combinations of $10 \mu \mathrm{mol} \mathrm{L}^{-1} \mathrm{Cd}$ and $25 \mu \mathrm{mol} \mathrm{L}^{-1} \mathrm{Zn}$ with MAA, while with SNA the same band also appeared in the treatment with single $50 \mu \mathrm{mol} \mathrm{L}-1 \mathrm{Zn}$.

\section{DISCUSSION}

Proteins, as direct gene products, reflect characteristic gene expression. Numerous researches revealing the full genome sequence of model plants, such as Arabidopsis and rice, have been published recently (48-50). However, gene sequence does not give complete information about gene function, developmental and regulatory biology or biochemical kinetics (51). Proteins are macromolecules directly responsible for most biological processes in a living cell, while protein function is directly influenced by posttranslational modifications, which cannot be followed by genome studies. Therefore, it is necessary to conduct proteomic studies which elucidate protein presence and role under certain environmental conditions (52). It is well known that heavy metal stress can activate a range of potential cellular mechanisms in plants, some of which being the mobilization of specific molecules such as phytochelatins and stress proteins that play a very significant role in $\mathrm{Cd}$ detoxification and tolerance in plants $(53,54)$. In a study performed on Datura innoxia, a $\mathrm{Cd}$-induced expression of numerous proteins in a molecular mass range from $10 \mathrm{kDa}$ to $70 \mathrm{kDa}$ was reported (55), while Cd-binding proteins have been isolated from Cd-exposed pea plants (56, 57). In our study, changes in protein expression were observed in tobacco seedlings as well as in leaves and roots of adult plants exposed to both cadmium and zinc. An enhanced expression of $116 \mathrm{kDa}$ protein was noticed in seedlings grown on media supplemented with both $\mathrm{Cd}$ and/or $\mathrm{Zn}$, except on the medium containing lower $\mathrm{Cd}$ and $\mathrm{Zn}$ concentration. Moreover, in leaves of adult plants, a $120 \mathrm{kDa}$ protein appeared after treatment with $10 \mu \mathrm{mol} \mathrm{L} \mathrm{L}^{-1} \mathrm{Cd}$, both concentrations of $\mathrm{Zn}$, as well as in combined treatments of $10 \mu \mathrm{mol}$ $\mathrm{L}^{-1}$ and $15 \mu \mathrm{mol} \mathrm{L}{ }^{-1} \mathrm{Cd}$ with $50 \mu \mathrm{mol} \mathrm{L}^{-1} \mathrm{Zn}$. In general, no specific effect of cadmium on protein profiles could be observed based on the SDS-PAGE results obtained in this study. Namely, both metals induced similar changes in protein patterns in tobacco seedlings and plants. In a study of $\mathrm{Cd}$ and $\mathrm{Zn}$ effect on leaves of Arabis paniculata, most identified 
proteins suggested that $\mathrm{Zn}$ and $\mathrm{Cd}$ share similar pathway to certain extent (58). However, our investigation was restricted to cellular proteins which can be easily extracted due to their high solubility in aqueous buffers at neutral $\mathrm{pH}$. Several publications report that heavy metals affect the rigidity of the cell wall and the cell membrane as well as the adsorption of certain secreted proteins to the cell wall (59-61). Therefore, in search of a more reliable molecular marker of heavy metal stress, some additional analyses should be performed. First of all, in order to identify the complete set of cadmium- and/or zinc-induced proteins the SDS-PAGE analyses of expression patterns should be extended to membrane and extracellular proteins. Moreover, 2D-PAGE electrophoresis should be applied, since this technique has a higher resolving power for separating complex mixtures of heterogenous polypeptides than SDSPAGE. Finally, employing 2D-PAGE in combination with mass spectrometry analyses will allow some of the heavy metal stress related proteins to be identified and their localization, modifications, interactions, activities, and ultimately their function to be determined.

Jomová and Morovič (13) found enhanced protein signals in the pattern of cellular stress protein expression in root tips of Lupinus luteus after exposure to $\mathrm{Cd}$ and suggested that increased proteosynthetic activity indicated the possible participation of these proteins in the cell defence reactions. It has been documented that heavy metals, as other abiotic stressors, can induce formation of reactive oxygen species (ROS) (62). The excess ROS produced under abiotic stress leads to oxidative damages of lipids, proteins, and nucleic acids (63). When exposed to such unfavourable environmental conditions, plants activate an arsenal of defence mechanisms, both passive and active. The active defence responses require de novo synthesis of proteins, some of these being antioxidative enzymes such as the superoxide dismutase, ascorbate peroxidase, gluthatione reductase, and class III plant peroxidases (64). Since elevated activities of these particular enzymes as well as an increased number of their isoforms were found in tobacco tissues exposed to $\mathrm{Cd}$ and/or Zn (Šikić et al. unpublished results), it is possible that at least some of the detected proteins belong to this group of defenders of plant cells. A study conducted with $\mathrm{Cd}$ on whole rice seeds, including the endosperm during germination, showed that similar proteins increased in response to $\mathrm{Cd}$ as with $\mathrm{Cu}$, so it appears that these proteins are involved in a general metal or stress response (18).

Except at the proteome level, abiotic stress can induce changes in posttranslational modifications, among which glycosylation is the most frequent one. Many proteins destined for secretion or expression at the surface of plant cells are glycoproteins. $\mathrm{N}$ - as well as O-glycosylation are essential protein modifications required for many different aspects of their structure and function, including their targeting to the appropriate destinations, their stability, solubility and antigenicity, as well as their capacity to be recognized by receptors. In several studies it was reported that protein glycosylation could have an important role in plant response to different abiotic stresses $(28,29,33)$. However, the influence of heavy metals on protein glycosylation has been poorly studied so far and only one extensive investigation could be found (31). In our study, characterization of glycosylated proteins was performed by lectin-based glycan profiling, the essence of which is to extract core information (like N-glycosylated or O-glycosylated, high-mannose type or complex type, core-fucosylated or not, fully or partially sialylated and other information) about glycan structures by means of lectin affinity technology (65). The use of lectins in glycan profiling provides considerable advantages, such as discrimination between the isomers on the basis of biological rather than physicochemical principles (66). Lectin-based glycan profiling has already been successfully applied in several plant glycoprotein studies $(23,26,27)$. In the present research, differences between control and treated tobacco tissues were more pronounced in glycoprotein compared to soluble protein pattern, which suggests that the oligosaccharide structures could be important determinants for heavy metal stress.

Analysis of N-glycosylated proteins from tobacco seedlings, leaves, and roots revealed common glycoproteins, which implies an enhanced protein glycosylation in all tobacco tissues after exposure to heavy metal stress. Namely, numerous papers indicate that $\mathrm{N}$-glycans can protect protein from proteolytic degradation and are responsible for thermal stability, solubility, and biological activity of the protein (32, 67). Komatsu et al. (30) reported that stress induced by a low temperature changed reactivity of 12 out of 22 glycoproteins detected with Con A in rice. Moreover, in tobacco roots, additional glycoproteins of $43 \mathrm{kDa}$ and $70 \mathrm{kDa}$ were detected with Con $\mathrm{A}$, which is in agreement with the fact that plant roots 
are the main site of heavy metals uptake and thus serve as the first barrier in defence mechanism. Interestingly, when GNA lectin was applied, all treated tobacco tissues revealed the bands, which according to their molecular weight (40 $\mathrm{kDa}$ in seedlings as well as 43 $\mathrm{kDa}$ in leaves and roots) corresponded to signals detected with horseradish peroxidase antibody (Šikić et al. unpublished results). Since most of the plant peroxidases are glycoproteins, this result suggests enhanced expression and glycosylation of this enzyme which has a very important role in plant defence against ROS (64). However, to be completely certain about this, more elaborated techniques for characterising protein and glycan part of glycoproteins further by their isoelectric point and molecular weight as well as by mass spectrometry should be applied. This would give significant information about the expressed glycoslyated proteins that are apparently subdued to changes in glycosylation during the exposure to heavy metal treatments. Lectin GNA revealed $\mathrm{N}$-glycosylated proteins of high-mannose type of lower molecular weight (up to $28 \mathrm{kDa}$ ) in seedlings, leaves and roots of tobacco exposed to heavy metals, which proves enhanced protein glycosylation that occurs in ER. Zhang et al. (32) reported that $\mathrm{N}$-glycosylation has a key role in response to abiotic stress and its absence leads to accumulation of damaged proteins in ER.

Lectin DSA, which mostly binds to Gal-(1,4)GlcNAc, detected glycoproteins with complex and/or hybrid $\mathrm{N}$-glycans in tobacco seedlings and adult plants. In treated leaves, only the glycoprotein of $40 \mathrm{kDa}$ was observed, while glycoslyated proteins of $50 \mathrm{kDa}$ and $60 \mathrm{kDa}$ were detected in root tissue after exposure to certain treatments. This result confirms enhanced modification of $\mathrm{N}$-glycan component, which occurs in GA, where complex and hybrid $\mathrm{N}$-glycans are formed $(68,69)$. Correct $\mathrm{N}$-glycosylation is important for normal growth and morphology of plant cells (70). Moreover, recent investigations, conducted on the model plant Arabidopsis thaliana, suggest that plant cell capability to form complex $\mathrm{N}$-glycan is very important in response to abiotic stress $(28,32)$. Kang et al. (29) reported that $A$. thaliana resistance to salt stress requires maturation of $\mathrm{N}$-glycosylated proteins in GA. Moreover, von Schaewen et al. (71) reported that A. thaliana mutants defective in complex $\mathrm{N}$-glycans show enhanced salt sensitivity, establishing that complex N-glycans protect plants from salt and osmotic stress.
Information about plant O-glycans are scarce. In plants, O-glycosylation has been described mainly for the hydroxyl groups of Hyp, Ser, and Thr residues. Plant and mammalian O-glycans are usually considered structurally different. The main O-glycosylated proteins in plants, extensins and arabinogalactan proteins (AGPs), belong to a large group of glycoproteins known as Hyp-rich glycoproteins (HRGPs). HRGPs are involved in many aspects of plant growth and development (72), and many effects of O-linked glycosylation on the biological activity of these proteins have been described (73). In our study, PNA, which specifically recognizes the $\beta$-Gal$(1,3)$-GalNAc sequence present in O-glycans, revealed several glycoproteins that also reacted with GNA. This result suggests that these proteins might possess both $\mathrm{N}$ - and O-glycosylation sites, although PNA and GNA may alternatively recognize different glycoproteins of similar molecular size, which are not resolved in SDSPAGE (26). In seedlings treated with $50 \mu \mathrm{mol} \mathrm{L}^{-1} \mathrm{Zn}$ and combined treatments $10 \mu \mathrm{mol} \mathrm{L}^{-1} \mathrm{Cd}$ and $50 \mu \mathrm{mol} \mathrm{L}^{-1} \mathrm{Zn}$ as well as $15 \mu \mathrm{mol} \mathrm{L}^{-1} \mathrm{Cd}$ and $25 \mu \mathrm{mol} \mathrm{L}^{-1} \mathrm{Zn}$ PNA detected glycoproteins of $16 \mathrm{kDa}$ and $17 \mathrm{kDa}$, which were not present in control tissues. In tobacco leaves and roots no band was detected in control tissues with PNA, while the majority of treatments responded with at least one band. Interestingly, the greatest number of PNA-reacting proteins was found after exposure to $10 \mu \mathrm{mol} \mathrm{L} \mathrm{L}^{-1} \mathrm{Cd}$ as well as to $50 \mu \mathrm{mol} \mathrm{L}^{-1} \mathrm{Zn}$ in tobacco leaves. These findings indicate that heavy metal stress can also induce O-glycosylation, even though it is difficult to say which type of plant O-glycoproteins these bands belong to. To get this answer, some more powerful techniques such as HPAEC-PAD and mass spectrometry should be applied.

MAA and SNAdetected sialic acids in glycoproteins of tobacco tissues. Sialylated glycoconjugates have already been found in suspension-cultured cells of Arabidopsis thaliana (47), in cellular and extracellular proteins of sugar beet tissue lines (23) as well as in soluble cellular glycoproteins of Mammillaria gracilis (24), which suggests that a genetic and enzymatic basis for sialylation exits in plants. In our study, the $43 \mathrm{kDa}$ glycoprotein from all tobacco seedlings reacted with MAA, but also with GNA and PNA. These findings indicate that the $43 \mathrm{kDa}$ is a multiglycosylated protein which has sialic acid (NeuAc) $\alpha(2,3)$-linked to galactose $(\mathrm{Gal})$. This suggests that this could be a stress-related protein. Balen et al. (27) reported enhanced sialylation of proteins in plant tissues 
obtained in in vitro culture, which indicates that sialylation could be induced by stressful environmental conditions. Arillo et al. (74) pointed out that the sialic acid content can be used as an index for environmental stress. Moreover, it was found that increased ROS generation in human $(75,76)$ and animal cells $(77)$ can be correlated with the overproduction of sialoglycoproteins.

Considering all the glycoprotein results, the greater number of glycosylated proteins was detected in tobacco seedlings compared to both leaves and roots of adult plants. In this study, control seedlings reacted with all the applied lectins, while the majority of detected bands were common for all samples. This result is in accordance with the findings that glycosylation has an important role during plant growth and development $(19,20,22-25)$. On the other hand, in leaves and roots of adult plants, only Con A among the applied lectins reacted with control samples. Therefore, the majority of detected glycoproteins in these tobacco tissues can be considered as a result of enhanced glycosylation due to heavy metal stress. Furthermore, the difference in glycosylation pattern between $\mathrm{Cd}$ and $\mathrm{Zn}$ application on tobacco seedlings and adult plants could not be determined since enhanced glycosylation was noticed after treatment with either metal alone or in combination. Therefore, it can be concluded that both metals induced $\mathrm{N}$ - and O-glycosylation as a result of changed environmental conditions, although more sophisticated analytical techniques should be employed to acquire more information.

\section{Acknowledgements}

The financial support of this work was provided by The Ministry of Science, Education, and Sports of the Republic of Croatia within the project 1191191196-1200

\section{REFERENCES}

1. Das P, Samantaray S, Rout GR. Studies on cadmium toxicity in plants: a review. Environ Pollut 1997;98:29-36.

2. Skórzyńska-Polit E, Baszyński T. Differences in sensitivity of the photosynthetic apparatus in Cd-stressed runner bean plants in relation to their age. Plant Sci 1997;128:11-21.

3. Sanità di Toppi L, Gabbrielli R. Response to cadmium in higher plants. Environ Exp Bot 1999;41:105-30.

4. Shah K, Kumar RG, Verma S, Dubey RS. Effect of cadmium on lipid peroxidation, superoxide anion generation and activities of antioxidant enzymes in growing rice seedlings. Plant Sci 2001;161:1135-44.

5. Romero-Puertas MC, Palma JM, Gómez M, del Río LA, Sandalio LM. Cadmium causes the oxidative modifications of proteins in pea plants. Plant Cell Environ 2002;25:67786.

6. Aravind P, Prasad MNV. Zinc alleviates cadmium-induced oxidative stress in Ceratophyllum demersum L.: a free floating freshwater macrophyte. Plant Physiol Biochem 2003;41:391-7.

7. Aravind P, Prasad MNV. Modulation of cadmium-induced oxidative stress in Caratophyllum demersum by zinc involves ascorbate-glutathion cycle and glutathione metabolism. Plant Physiol Biochem 2005;43:107-16.

8. Vallee BL, Falchuk KH. The biochemical basis of zinc physiology. Physiol Rev 1993;73:79-118.

9. Ullrich SM, Ramsey MH, Helios-Rybicka E. Total and exchangeable concentrations of heavy metal in soils near Bytom, an area of $\mathrm{Pb} / \mathrm{Zn}$ mining and smelting in upper Silesia, Poland. Appl Geochem 1999;14:187-96.

10. Wu F, Zhang G. Alleviation of cadmium-toxicity by application of zinc and ascorbic acid in barley. J Plant Nutr 2002;25:2745-61.

11. Hassan MJ, Zhang G, Wu F, Wie K, Chen Z. Zinc alleviates growth inhibition and oxidative stress caused by cadmium in rice. J Plant Nutr Soil Sci 2005;168:255-61.

12. Tkalec M, Prebeg T, Roje V, Pevalek-Kozlina, Ljubešić N. Cadmium induced responses in duckweed Lemna minor L. Acta Physiol Plant 2008;30:881-90.

13. Jomová K, Morovič M. Effect of heavy metal treatment on molecular changes in root tips of Lupinus luteus L. Czech J Food Sci 2009;27(Special issue):S386-9.

14. Siedlecka A. Some aspects of interactions between heavy metals and plant mineral nutrients. Acta Soc Bot Pol 1995;64:265-72.

15. AI-Rumaih MM, Rushdy SS, Warsy AS. Alteration in the protein electrophoretic patterns of cowpea, (Vigna unguiculata L.) treated with cadmium in the presence or absence of gibberellic acid. Saudi J Biol Sci 2002;9:47-56.

16. Sobkowiak R, Deckert J. Proteins induced by cadmium in soybean cells. J Plant Physiol 2006;163:1203-6.

17. Pós V, Hunyadi-Gulyás É, Caiazzo R, Jócsák I, Medzihradszky $\mathrm{KF}$, Lukács N. Induction of pathogenesis-related proteins in intercellular fluid by cadmium stress in barley (Hordeum vulgare L.) - A proteomic analysis. Acta Aliment 2011;40:16475.

18. Ahsan N, Lee SH, Lee DG, Lee H, Lee SW, Bahk JD, Lee BH. Physiological and protein profiles alternation of germinating rice seedlings exposed to acute cadmium toxicity. C R Biol 2007;330:735-46.

19. Stevens LH, Stoopen GM, Elbers IJ, Molthoff JW, Bakker HAC, Lommen A, Bosch D, Jordi W. Effect of climate conditions and plant developmental stage on the stability of antibodies expressed in transgenic tobacco. Plant Physiol 2000;124:173-82.

20. Elbers I JW, Stoopen GM, Bakker H, Stevens LH, Bardor M, Molthoff JW, Jordi WJRM, Bosch D, Lommen A. Influence of growth conditions and developmental stage on $\mathrm{N}$-glycan heterogeneity of transgenic immunoglobulin $\mathrm{G}$ and endogenous proteins in tobacco leaves. Plant Physiol 2001;126:1314-22. 
21. Krsnik-Rasol M, Čipčić H, Poljuha D, Hagége D. Electrophoretic protein patterns of sugar beet tissue lines. Phyton 2000;41:13-20.

22. Balen B, Milošević J, Krsnik-Rasol M. Protein and glycoprotein patterns related to morphogenesis in Mammillaria gracillis Pfeiff. tissue culture. Food Technol Biotechnol 2002;40:275-80

23. Pavoković D, Šola I, Hagége D, Krsnik-Rasol M. Sugarinduced changes in cellular and extracellular protein and glycoprotein patterns of sugarbeet cell lines. Acta Bot Croat 2007;66:127-34

24. Balen B, Zamfir A, Vakhrushev SY, Krsnik-Rasol M, PeterKatalinić J. Determination of Mammillaria gracillis N-glycan patterns by ESI Q-TOF mass spectrometry. Croat Chem Acta 2005;78: 463-77.

25. Balen B, Krsnik-Rasol M, Zamfir AD, Milošević J, Vakhrushev SY, Peter-Katalinić J. Glycoproteomic survey of Mammillaria gracillis tissues grown in vitro. J Proteome Res 2006;5:1658-66.

26. Balen B, Krsnik-Rasol M, Zamfir AD, Zadro I, Vakhrushev SY, Peter-Katalinić J. Assessment of N-glycan heterogeneity of cactus glycoproteins by one-dimensional gel electrophoresis and matrix-assisted laser desorption/ionization time-of-flight mass spectrometry. J Biomol Tech 2007;18:150-60.

27. Balen B, Peharec P, Krsnik-Rasol M. Developmentally specific soluble and membrane proteins and glycoproteins in Mammillaria gracillis Pfeiff. (Cactaceae) tissue culture. Acta Bot Croat 2008;67:221-7.

28. Koiwa H, Li F, McCully MG, Mendoza I, Koizumi N, Manabe Y, Nakagawa Y, Zhu J, Rus A, Pardo JM, Bressan RA, Hasegawa PM. The STT3a subunit isoform of the Arabidopsis oligosaccharyltransferase controls adaptive responses to salt/osmotic stress. Plant Cell 2003;15:227384.

29. Kang JS, Frank J, Kang CH, Kajiura H, Vikram M, Ueda A, Kim S, Bahk JD, Triplett B, Fujiyama K, Lee SY, von Schaewen A, Koiwa H. Salt tolerance of Arabidopsis thaliana requires maturation of $\mathrm{N}$ glycosylated proteins in the Golgi. Proc Natl Acad Sci USA 2008;105:5933-8.

30. Komatsu S, Yamada E, Furukawa K. Cold stress changes the concanavalin A-positive glycosylation pattern of proteins expressed in the basal parts of rice leaf sheaths. Amino Acids 2009;36:115-23.

31. Carpena RO, Vázquez S, Esteban E, Fernández-Pascual M, de Felipe MR, Zornoza P. Cadmium-stress in white lupin: effects on nodule structure and functioning. Plant Physiol Biochem 2003;41:911-9.

32. Zhang M, Henquet M, Chen Z, Zhang H, Zhang Y, Ren $\mathrm{X}$, van der Krol S, Gonneau M, Bosch D, Gong Z. LEW3, encoding a putative alpha-1,2-mannosyltransferase (ALG11) in N-linked glycoprotein, plays vital roles in cell-wall biosynthesis and the abiotic stress response in Arabidopsis thaliana. Plant J 2009;60:983-99.

33. Johnson KL, Jones BJ, Bacic A, Schultz CJ. The fasciclinlike arabinogalactan proteins of Arabidopsis. A multigene family of putative cell adhesion molecules. Plant Physiol 2003;133:1911-25.

34. Havir EA, Brisson LF, Zelitch I. Distribution of catalase isoforms in Nicotiana tabacum. Phytochemistry 1996;41:699-702.

35. Ganapathi TR, Suprasanna P, Rao PS, Bapat VA. Tobacco (Nicotiana tabacum L.) - A model system for tissue culture interventions and genetic engineering. Indian J Biotechnol 2004:3:171-84

36. Garnier L, Simon-Plas F, Thuleau P, Agnel JP, Blein JP, Ranjeva R, Montillet JL. Cadmium affects tobacco cells by a series of three waves of reactive oxygen species that contribute to cytotoxicity. Plant Cell Environ 2006;29:195669.

37. Gratão PL, Pompeu GB, Capaldi FR, Vitorello VA, Lea PJ, Azevedo RA. Antioxidant response of Nicotiana tabacum cv. Bright Yellow 2 cells to cadmium and nickel stress. Plant Cell Tiss Organ Cult 2008;94:73-83.

38. Murashige T, Skoog F. A revised medium for rapid growth and bioassays with tobacco tissue cultures. Plant Physiol 1962;15:473-97.

39. Gichner T, Ptácek O, Stavreva DA, Plewa MJ. Comparison of DNA damage in plants as measured by single cell gel electrophoresis and somatic leaf mutations induced by monofunctional alkylating agents. Environ Mol Mutagen 1999;33:279-86.

40. Staples RC, Stahmann MA. Changes in proteins and several enzymes in susceptible bean leaves after infection by the bean rust fungus. Phytopatology 1964;54:760-4.

41. Bradford MM. A rapid and sensitive method for the quantitation of microgram quantities of protein utilizing the principle of protein-dye binding. Anal Biochem 1976;72:24854.

42. Laemmli UK. Cleavage of structural proteins during the assembly of the head of bacteriophage T4. Nature 1970;227:680-5.

43. Blum $\mathrm{H}$, Beier $\mathrm{H}$, Gross HJ. Improved silver staining of plant proteins, RNA and DNA in polyacrylamide gels. Electrophoresis 1987;8:93-9.

44. Hrubá P, Tupý J. N-glycoproteins specific for different stages of microspore and pollen development in tobacco. Plant Sci 1999;141:29-40.

45. Yamashita K, Totani K, Ohkura T, Takasaki S, Goldstein IJ, Kobata A. Carbohydrate binding properties of complex-type oligosaccharides on immobilized Datura stramonium lectin. J Biol Chem 1987;262:1602-7.

46. Mérant C, Messouak A, Cadoré JL, Monier JC. PNA-binding glycans are expressed at high levels on horse mature and immature $\mathrm{T}$ lymphocytes and a subpopulation of $\mathrm{B}$ lymphocytes. Glycoconj J 2005;22:27-34.

47. Shah MM, Fujiyama K, Flynn CR, Joshi L. Sialylated endogenous glycoconjugates in plant cells. Nature Biotechnol 2003;21:1470-1.

48. Rangan L, Vogel C, Srivastava AK. Analysis of context sequence surrounding translation initiation site from complete genome of model plants. Mol Biotechnol 2008;39:207-13.

49. Zhang W, Wu Y, Schnable JC, Zeng Z, Freeling M, Crawford GE, Jiang J. High-resolution mapping of open chromatin in the rice genome. Genome Res 2012;22:151-62.

50. Kyndt T, Denil S, Haegeman A, Trooskens G, De Meyer T, Van Criekinge W, Gheysen G. Transcriptome analysis of rice mature root tissue and root tips in early development by massive parallel sequencing. J Exp Bot 2012;63: 2141-57.

51. Qureshi MI, Qadir S, Zolla L. Proteomics-based dissection of stress-responsive pathways in plants. J Plant Physiol 2007; 164:1239-60.

52. Porubleva L, Chitnis PR. Proteomics: A powerful tool in the post-genomic era. Indian J Biochem Biophys 2000;37:360-8. 
53. Sanita di Toppi L, Gabbrielli R. Response to cadmium in higher plants. Environ Exp Bot 1999;41:105-30.

54. Cobbett CS. Phytochelatins and their roles in heavy metal detoxification. Plant Physiol 2000;123:825-32.

55. Delhaize E, Robinson NJ, Jackson PJ. Effects of cadmium on gene expression in cadmium-tolerant and cadmiumsensitive Datura innoxia cells. Plant Mol Biol 1989;12:48797.

56. Grünhage L, Weigel H, Ilge D, Jäger H. Isolation and partial characterization of a cadmium-binding protein from Pisum sativum. J Plant Physiol 1985;119:327-34.

57. Evans IM, Gatehouse LN, Gatehouse JA, Robinson NJ, Croy RRD. A gene from pea (Pisum sativum L.) with homology to metallothionein genes. FEBS Letters 1990;262:29-32.

58. Zeng XW, Qiu RL, Ying RR, Tang YT, Tang L, Fang XH The differentially-expressed proteome in $\mathrm{Zn} / \mathrm{Cd}$ hyperaccumulator Arabis paniculata Franch. in response to $\mathrm{Zn}$ and Cd. Chemosphere 2011;82:321-8.

59. Hirano Y, Tsumuraya Y, Hashimoto Y. Characterization of spinach leaf $\alpha$-1-arabinofuranosidases and $\beta$-galactosidases and their synergistic action on an endogenous arabinogalactanprotein. Physiol Plant 1994;92:286-96.

60. Kataoka T, Furukawa J, Nakanishi TM. The decrease of extracted apoplast protein in soybean root tip by aluminium treatment. Biol Plant 2003;36:445-9.

61. Scheel T, Pritsch K, Schloter M, Kalbitz K. Precipitation of enzymes and organic matter by aluminum - Impacts on carbon mineralization. J Plant Nutr Soil Sci 2008;171:900-7.

62. Maksymiec W. Signaling responses in plants to heavy metal stress. Acta Physiol Plant 2007;29:177-87.

63. Hossain Z, Nouri M-Z, Komatsu S. Plant cell organelle proteomics in response to abiotic stress. J Proteome Res 2012;11:37-48

64. Almagro L, Gómez Ros LV, Belchi-Navarro S, Bru R, Ros Barceló A, Pedreño MA. Class III peroxidases in plant defence reactions. J Exp Bot 2009;60:377-90.

65. Hirabayashi J. Lectin-based structural glycomics: Glycoproteomics and glycan profiling. Glycoconj J 2004;21:35-40.

66. Kuno A, Uchiyama N, Koseki-Kuno S, Ebe Y, Takashima S, Yamada M, Hirabayashi J. Evanescent-field fluorescenceassisted lectin microarray: a new strategy for glycan profiling Nat Methods 2005;2:851-6.
67. Zhang H, Ohyama K, Boudet J, Chen Z, Yang J, Zhang M, Muranaka T, Maurel C, Zhu JK, Gong Z. Dolichol biosynthesis and its effects on the unfolded protein response and abiotic stress resistance in Arabidopsis. Plant Cell 2008;20:1879-98

68. Fitchette AC, Gomord V, Chekkafi A, Faye L. Distribution of xylosylation and fucosylation in the plant Golgi apparatus. Plant J 1994;5:673-82.

69. Oxley D, Munro SL, Craik DJ, Bacic A. Structure of Nglycans on the S3- and S6-allele stylar self-incompatibility ribonucleases of Nicotiana alata. Glycobiology 1996;6:6118.

70. Frank J, Kaulfürst-Soboll H, Rips S, von Schaewen A. Comparative analyses of Arabidopsis complex glycan1 mutants and genetic interaction with staurosporin and temperature sensitive3a. Plant Physiol 2008;148:1354-67.

71. von Schaewan A, Frank J, Koiwa H. Role of complex $\mathrm{N}$-glycans in plant stress tolerance. Plant Signal Behav 2008;3:871-3.

72. Seifert GJ, Roberts K. The biology of arabinogalactan proteins. Annu Rev Plant Biol 2007;58:137-61.

73. Gomord V, Fitchette AC, Menu-Bouaouiche L, Saint-JoreDupas C, Plasson C, Michaud D, Faye L. Plant-specific glycosylation patterns in the context of therapeutic protein production. Plant Biotechnol J 2010;8:564-87.

74. Arillo A, Margiocco C. Melodia F. The gill sialic acid content as an index of environmental stress in rainbow trout, Salmo gairdneri, Richardson. J Fish Biol 1979;15:405-10.

75. Honglertsakul C, Opanuraks J, Kittikowit W, Boonla C, Wunsuwan R, Tosukhowong P. Increased urinary excretions of oxidative stress biomarkers and sialic acid associated with severity of bladder tumors. Thai J Surg 2007;28:133-7.

76. Goswami K, Nandeesha H, Koner BC, Nandakumar DN. A comparative study of serum protein-bound sialic acid in benign and malignant prostatic growth: possible role of oxidative stress in sialic acid homeostasis. Prostate Cancer Prostatic Dis 2007;10:356-9.

77. Erdogan HM, Karapehlivan M, Citil M, Atakisi O, Uzlu E, Unver A. Serum sialic acid and oxidative stress parameters changes in cattle with leptospirosis. Vet Res Commun 2008;32:333-9. 


\section{Sažetak}

\section{KADMIJ I CINK INDUCIRAJU SLIČNE PROMJENE U UZORKU PROTEINA I GLIKOPROTEINA U KLIJANCIMA I ODRASLIM BILJKAMA DUHANA (NICOTIANA TABACUM L.)}

Ispitivali smo učinke $10 \mu \mathrm{mol} \mathrm{L}{ }^{-1}$ i $15 \mu \mathrm{mol} \mathrm{L}^{-1}$ kadmija (Cd), neesencijalnoga toksičnog elementa i 25 $\mu \mathrm{mol} \mathrm{L}{ }^{-1}$ i $50 \mu \mathrm{mol} \mathrm{L}^{-1}$ cinka $(\mathrm{Zn})$, esencijalnog mikronutrijenta, na proteine i glikoproteine u klijancima i odraslim biljkama Nicotiana tabacum L. nakon izlaganja svakomu metalu posebno ili njihovim kombinacijama. Promjene kod nekoliko polipeptida koje su uočene u klijancima i listovima odraslih biljaka nisu bile brojne, dok su one najvažnije zabilježene u uzorku ukupnih topljivih proteina u korijenu biljke. Razlike između kontrole i tretiranog tkiva duhana bile su izraženije kod glikoproteina koji su analizirani primjenom različitih lektina. Većina glikoproteina uočenih u listovima i korijenu odraslih biljaka može se smatrati rezultatom povećane glikozilacije zbog stresa koji uzrokuju teški metali. Nije bilo moguće utvrditi razliku u glikoproteinima između tretiranja klijanaca i odraslih biljaka duhana kadmijem i cinkom jer je povećana glikozilacija utvrđena i nakon tretmana svakim metalom posebno i nakon tretmana njihovim kombinacijama. Stoga se može zaključiti da su, kao rezultat promijenjenih uvjeta u okolišu, oba metala potaknula N- i O-glikozilaciju.

KLJUČNE RIJEČI: glikozilacija, lektini, teški metali, uzorak proteina

\section{CORRESPONDING AUTHOR:}

Biljana Balen, $\mathrm{PhD}$

Department of Molecular Biology,

Faculty of Science, University of Zagreb

Horvatovac 102a, Zagreb, Croatia

E-mail: bbalen@zg.biol.pmf.hr 